\title{
FINANCING OF THE AGRICULTURE IN SERBIA: STATE AND PROSPECTS ${ }^{1}$
}

\author{
Ana Jolović, ${ }^{2}$ Zoran Njegovan ${ }^{3}$, Mirolsav Čavlin $^{4}$
}

\begin{abstract}
Summary
Serbian agriculture has a relatively poor performance through the decades. One of the main factors is inadequate financing system for such purposes in spite of numbered financial institutions and financial sources. Especially the financial resources and its lending have a poor performance in primary production of farmers and agricultural SME's, much poorer than in other cases and economy sectors. Governing the research concerning state and perspectives of agriculture financing in Serbia, the authors has formulated the goal to examine and determine the main factors that are shaping financing sector performance and its involvement in the business of agriculture. Also the goal was to recognize the main tendencies in the sphere of financing the agriculture as well to point the connection and interrelation between financing sector and government efforts to put much more efforts to agricultural development and institution building concerning financing at the first place.
\end{abstract}

Key words: financing, agriculture, financial institutions, financial sources, banks, leasing firms, financial and development funds, microfinance organizations, integrators.

JEL: $Q 16, M 24$

1 Paper is a part of research within the project no. III 46006 - Sustainable agriculture and rural development in the function of accomplishing strategic objectives of the Republic of Serbia in the Danube region, financed by the Ministry of Education, Science and Technological Development of the Republic of Serbia, project period 2011-2014.

2 Ana Jolović, Ph.D., Assistant Professor, University of Management and Economics ISM, Arkliu Street 18, Vilnius, Lithuania, Phone: +381 637503 567, E-mail: anjol@faculty.ism.lt

3 Zoran Njegovan, Ph.D., Full Professor, University of Novi Sad, Faculty of Agriculture, Trg Dositeja Obradovića 8, 21000 Novi Sad, Phone: +381 648465 062, E-mail: njegovan@polj.uns.ac.rs

4 Miroslav Čavlin, Ph.D., Assistant Professor, FIMEK, Cvećarska Street no. 2, 21000 Novi Sad, Serbia, Phone: +381 21400 484, E-mail: cmiros@gmail.com

EP 2014 (61) 1 (127-137) 


\section{Introduction}

With approximately $10 \%$ of GDP, $21 \%$ of employment, and $23 \%$ of total exports, agriculture is one of the most important economic sectors in Serbia. Agriculture accounts for a significant share of foreign trade, revealing a surplus of USD 150 million in 2005, which increased to USD 640 million in 2010. Also the significance of agriculture is reflected in, among other things, its contribution to the creation of gross domestic product. In the period from 2002 to 2010 , the share of agriculture in national GDP ranged from $14.3 \%$ to $10.6 \%$ and the share of food industry ranged from $5.3 \%$ to $4.8 \%$ (Tomić, Njegovan, 2013). Also concerning the period 2001-2012, food, beverage and agriculture was the second sector by FDIs, more than telecommunication, retail and automotive industry. In 2010 the Serbian Government declared agriculture to be of strategic economic importance; this role was reinforced during the recent election campaign.

Despite its economic and political importance, the Serbian agricultural sector is still hampered by a variety of constraints limiting its full potential (Pejanović, Njegovan, 2009). Aside from outdated production technologies and machinery, the lack of adequate infrastructure (e.g. storage/cooling facilities) and inadequate irrigation and drainage systems, the lack of sufficient agricultural finance in comparison to other sectors is considered by many observers to be one of the major impediments to the growth and development of the sector (Njegovan et al., 2009). Agriculture accounted for only $2.7 \%$ of the Serbian 2011 budget, with half of this amount consisting of budget-financed subsidies for price and input support (Njegovan, Draganić, 2013). Officially, only about $3 \%$ of bank loans are in the agricultural and food processing industry. This number, however, might actually be higher due to the fact that banks use different classifications, classifying those loans as corporate, industrial, retail, or other.

\section{Current status of agribusiness financing}

The conclusion reached in the assessment is that the Serbian financial sector offers a wide range of loan products to the agricultural sector (Petraković et al., 2003). The list of active lenders in this market includes banks, state funds, leasing companies, microfinance organizations and integrators. Many of the interviewed lenders have a large number of agricultural loan products available that include grace periods, production-contract collateralization, equipment finance and input credit, among others, table 1 . However, agribusiness finance is significantly constrained both in terms of tenor and of local currency availability.

Table 1. Overall Lending to the Agricultural Sector by Organization Type

\begin{tabular}{|c|l|r|r|}
\hline No. & \multicolumn{1}{|c|}{ Name of the Bank } & \multicolumn{1}{c|}{ Value in EUR } & \multicolumn{1}{c|}{ Structure in \% } \\
\hline 1 & Banca Intesa & $58,601,000$ & $8.86 \%$ \\
\hline 2 & Nova Agrobanka & $47,306,835$ & $7.15 \%$ \\
\hline 3 & Komercijalna Bank & $45,185,983$ & $6.83 \%$ \\
\hline 4 & Societe Générale & $35,385,930$ & $5.35 \%$ \\
\hline 5 & AIK Bank & $24,457,922$ & $3.70 \%$ \\
\hline 6 & Hypo Alpe-Adria-Bank & $22,971,791$ & $3.47 \%$ \\
\hline
\end{tabular}




\begin{tabular}{|c|l|r|r|}
\hline No. & \multicolumn{1}{|c|}{ Name of the Bank } & \multicolumn{1}{c|}{ Value in EUR } & \multicolumn{1}{c|}{ Structure in \% } \\
\hline 7 & Credit Agricole Bank & $18,378,504$ & $2.78 \%$ \\
\hline 8 & Raiffeisen Bank & $17,367,948$ & $2.63 \%$ \\
\hline 9 & UniCredit Bank & $16,395,913$ & $2.48 \%$ \\
\hline 10 & ProCredit Bank & $16,358,052$ & $2.47 \%$ \\
\hline 11 & State Funds (Dev't Fund, etc.) & $153,780,303$ & $23.25 \%$ \\
\hline 12 & Leasing Companies & $38,022,600$ & $5.75 \%$ \\
\hline 13 & Microfinance Organizations & $6,650,000$ & $1.01 \%$ \\
\hline 14 & All Other Banks & $60,650,183$ & $9.17 \%$ \\
\hline 15 & Integrators (est.) & $100,000,000$ & $15.12 \%$ \\
\hline Total & & $661,512,964$ & $100.00 \%$ \\
\hline
\end{tabular}

Source: NBS, internal data (June 2012) and author's analysis.

Agribusinesses face significant constraints in their access to finance due to high risk aversion (Njegovan, 2005) and lack of market understanding by banks. The top five agricultural lenders in Serbia by volume are Banca Intesa, Nova Agrobanka, Societe Générale, Komercijalna Banka, and AIK Banka. Even those banks that strongly support the agricultural sector indicated that the primary reason for loan-applicant rejections was the perception that the creditworthiness of borrowers in agribusiness was weaker than of those in other sectors. In addition, there are numerous banks are reluctant to target the sector due to this same perceptions. Bank loans to agribusiness are predominately loans with shorter maturity ( $72 \%$ of all loans being for three years or less) and primarily extended to larger agro-processing businesses. Most loans (62\%) are made in EUR despite the fact that most agricultural production is for domestic consumption and is paid for (approximately 78\%) in RSD. Therefore, financing of long-term investment in RSD presents a significant constraint to the sector, and is a particular challenge for farmers and agribusinesses with RSD income. Banks are more active in lending to agriculture in AP of Vojvodina and most of them prefer to offer general products that can afterwards be structured for each borrower, which indicates they are not focused on providing value to their agricultural clients in terms of new, agro tailor-made product development. According to the NBS there is approximately EUR 419 million in outstanding loans to this sector as of end-of-year 2011.

It is worth of mentioning that the high level of "euroization" of Serbia's economy is a factor increasing currency risk for borrowers. As of end 2011, the euroization ratio of the total loan stock was, according to the NBS, slightly more than $77 \%$, while euroization on the deposit side was close to $70 \%$. Serbia has embarked upon a strategy for deeuroization. However, a significant risk for banks remains their indirect foreign currency exposure. Due to the high level of foreign exchange credit, banks are indirectly affected by exchange rate appreciations that reduce the ability of borrowers whose revenues are not in foreign exchange to service their debts, which is the majority of agro sector.

In addition to banks, a number of other institutions are active in financing the Serbian agricultural sector. The estimated agricultural portfolio held by non-bank organizations is around EUR 252 million. 
Leasing offers the potential to overcome some of the traditional challenges in agricultural financing, by providing an alternative solution for farmers and SMEs with limited collateral and credit history. Although financial leasing companies are well-established in Serbia, they are mainly focused on transport and automobile financing because of strong enterprise and consumer demand, as well as a liquid secondary market for vehicles. The top five agricultural lenders in Serbia by volume are Banca Intesa, Nova Agrobanka, Societe Générale, Komercijalna Banka, and AIK Banka. Concerning agricultural leasing it is a small fraction of the overall level of equipment financing provided by the leasing companies. It is limited to tractors and combines and a very few medium-size equipment investments, thus arriving at an average of about $6-7 \%$ of the overall portfolio of all leasing companies. Same as with bank loans, the bulk of products were either foreign-currency-denominated or foreign currency clause indexed.

Table 2. Agricultural leasing as percentage of overall number of new leases

\begin{tabular}{|l|r|r|}
\hline \multicolumn{1}{|c|}{ Leases with New Clients } & \multicolumn{1}{|c|}{$\mathbf{2 0 1 1}$} & \multicolumn{1}{|c|}{$\mathbf{2 0 1 0}$} \\
\hline (Total) All Leases with New Clients (EUR) & $256,982,328$ & $202,939,010$ \\
\hline (Total) Agricultural New Business (EUR) & $15,604,756$ & $14,288,920$ \\
\hline Agricultural New Business (\% of Total) & $6.07 \%$ & $7.04 \%$ \\
\hline
\end{tabular}

Source: Leasing Association of Serbia, internal data (2012) and analysis of authors.

There are a number of state-owned organizations and funds that provide lending or support to lending for the Serbian agricultural sector (Njegovan, Pejanović, 2009). The Serbian Development Fund does not break down the size of its portfolio by sector; however, a breakdown of current outstanding loans made to the agricultural sector since 2007 gives the estimate of EUR 134 million. The terms and conditions of these loans are very favourable, with significantly lower interest rates than those available in the market. Export Credit and Insurance Agency of Serbia - AOFI have stated that they provide a significant level of support to the agricultural sector mainly via food-processing exporters. They estimated their exposure to the agricultural sector to be roughly EUR 20 million, which is $33 \%$ of the capital of $A O F I$. In this context, the level of agricultural support by AOFI as a portion of its capital is significantly in excess of the sector's share of total exports of Serbia, which stands at $21 \%$. Vojvodina Guarantee Fund (VGF) provides guarantees to agribusiness, Graph 1.

Graph 1. Structure of Lending by the VGF

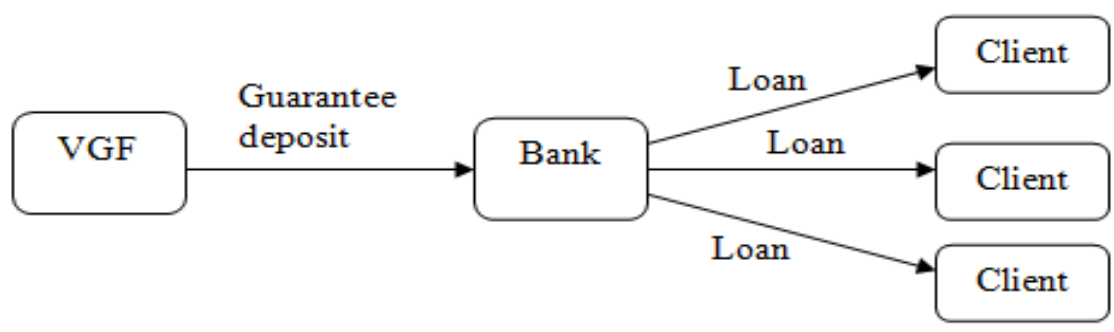

Source: AP Vojvodina Guarantee Fund, internal data, 2012. 
To date, they have guaranteed a portfolio of approximately EUR 20 million in the agricultural sector, of which EUR 10 million is current. Due to the lack of adequate regulation, the Vojvodina Guarantee Fund is registered with the Vojvodina Secretariat for Culture. This prevents the institution from sourcing additional funds in the market (through bank loans, bond sales or securitization).

The Vojvodina Provincial Fund for Agricultural Development has approximately EUR 15 million in its portfolio and about 1,000 borrowers who have borrowed at lower than commercial rates. Fund invests through two commercial banks due to the regulation that prohibits fund to directly lend money. Their main clients are farmers and, to some degree, SMEs. Three years ago Serbia established the Indemnity Fund of Serbia as a government entity responsible for system of public warehouses designed to support agribusinesses and lending to agribusinesses. The success of this fund has resulted in the introduction of warehouse receipts that are recognized by the NBS as adequate collateral for bank loans to agribusinesses.

Three non-bank microcredit institutions - MFI operate in Serbia at present, and all are forced to issue loans through commercial banks due to the lack of regulation for non-bank, non-deposit taking financial institutions. Their combined total portfolio is approximately EUR 16 million, spread across over 16,500 borrowers. Microcredit is made up mainly of entrepreneurial and agricultural production loans based on internationally accepted methodologies, ranging from EUR 300 to EUR 3,000, with the average loan amounting to between EUR 900 and EUR 1,100. MFI loan funds are mainly composed of donor capital and accumulated profits. AgroInvest, the largest of the three providers, accesses commercial credit from foreign social investors and international banks.

Food-processing companies, integrators, are an important source of lending and liquidity for farmers and SMEs in Serbia, although this is not measured in any formal way. Companies engage in barter operations with their suppliers (parity) in which they take inputs in exchange for crop sales upon harvest. In those cases the price is set according to parity at the time of contracting, prior to post-harvest delivery. Some estimates put this amount at a significant EUR 100 million at least.

In recent times, many major buyers/traders have started offering agreements with clearer input values, end product value, as well as more clearly expressing interest rates. Now the farmer repays the loan in commodity at market price on the day of the repayment at a more transparent rate rather than the usurious rates prevalent in the 1990s and early 2000s. There have been efforts by agricultural cooperatives and farmers' associations to gain more transparency on the terms and conditions of such financing to the sector. However, the markup terms (particularly for input prices of some types of seeds and fertilizer) are generally often unclear and in many cases lack an explicit "effective annual interest rate" that may better inform the farmers about the actual costs of this type of financing.

Food processing companies provide necessary resources through their own income or by retained earnings, in addition to accessing needed funds from banks. As a rule, it is not difficult for them to obtain loans, which are guaranteed by property (grain silos, production 
plants, etc.). These loans are not formally registered as agricultural loans, and the NBS does not require banks to specify in great detail the use of the loan by a borrower, only the general category. Borrowing levels for the main crops in Serbia in terms of the costs of basic production inputs, an analysis is provided here on the source of this estimate and the overall total of integrator finance. Assuming here, that $60 \%$ of the approximately 300,000 unregistered farmers borrow their primary input costs on their average ownership of 1 hectare of land, it can be seen the following: 180,000 hectares $\mathrm{x}$ average price of seeds per ha of EUR $200=$ EUR 36 million; 180,000 hectares $\mathrm{x}$ average price of fertilizer per ha of EUR $250=$ EUR 45 million; and 180,000 hectares $\mathrm{x}$ average price of pesticide per ha of EUR $100=$ EUR 19 million, that gives the total sum of approximately EUR 100 million per year.

Also it may be recognized the participation of private equity funds (Salford and InBev being two large food-related investments). They still do not invest in Serbian agriculture. Discussions with a private-equity practitioner in Belgrade indicated that private equity is limited by the same factors limiting FDI, which are beyond the scope of this agricultural lending study.

\section{Major constraints to agribusiness financing}

No single factor can explain why access to finance for agribusiness and farmers is poor. It is a complex of constraints that are interlinked and influenced by a variety of legal, economic, institutional, and behavioural factors. All those constraints can be broadly summarized as follows: inconsistent agricultural policy; inefficient subsidy programs; regulation disincentives or lack of regulation; few alternative sources of finance; lenders' knowledge and perception of risk in agribusiness; weak market leverage of agribusinesses; borrowers' psychology, knowledge and access to information; not taking advantage offered by the value chain concept; and high risk of the sector.

Banks that are focused on lending to agribusinesses pointed out the uncertainty in planning, inconsistency of Serbian agricultural policy, poorly-designed interest-rate subsidy programs and lack of borrowers leverage as the main obstacles to increasing lending. The relevant ministry has a high turnover of key people and changes priorities very often. This leads to unpredictability in cash flows in agribusiness and decreases the creditworthiness of potential clients. Interest rate subsidy programs do not involve consultation with the financial sector when the programs are designed, and as a result the way the programs are constructed in does not motivate banks to increase lending to the sector. Furthermore, subsidized loans negatively influence the credit market by sending wrong signals to agribusinesses about financing costs. The lack of an effective Cooperative Law and no efficient agribusiness associations hinder banks' ability to offer products that do not rely on creditworthiness of individual borrowers. Outreach costs could be decreased by enabling lenders to better support the activities of tens or hundreds of producers via one cooperative, rather than being forced to contract with hundreds of farmers individually. 
Banks that are not focused on lending to agribusinesses see the lack of desire on the part of bank owners/shareholders and upper management to increase exposure to this sector as the main constraint. They cite too many unresolved issues related to the policy environment, and too much uncertainty about the ability of agricultural producers and processors to meet their obligations, as the fundamental reasons for those strategic decisions. They also point out that only a small number of agricultural producers are included in modern market chains as they are largely uncompetitive, in addition to not having requested collateral, primarily high value real estate. In many cases the buildings are unregistered and land registers are incomplete. Furthermore, procedures for loan debt collection and contract enforcement are particularly very long in the rural areas of Serbia.

Constraints faced by the non-bank lending sector are mainly related to regulations. The lack of regulation for non-deposit taking credit institutions, combined with the official view that only banks can take lend money as their daily business, leaves this sector underdeveloped and unable to serve one segment of the market. In case of leasing, regulation on VAT results in leasing being less attractive to the clients than a bank loan. There is no regulation of operating leasing. This lack of regulation or lack of suitable regulation has negative impact to all SMEs, but due to specifics of agro sector it is even more prominent in case of agribusinesses.

\section{Recommendations to improve access to finance for agribusinesses}

Based on the interviews, discussions and research conducted, we make the following recommendations to facilitate an increase in the agricultural lending of commercial banks, non-bank lenders and state entities currently engaged in lending to farmers, agribusiness SMEs and agricultural cooperatives. The recommendations focus on measures that will help lenders to assess the creditworthiness of borrowers more favourably, and also to improve the lending environment in terms of legal, regulatory and similar constraints identified as pertaining to the agricultural sector.

These recommendations, serve to address many of the constraints identified by the lenders in terms of their outreach to the agricultural sector. On the basis of the key information learned from the lenders and background research, these recommendations are outlined as those that should be addressed by the government, financial institutions, or agribusinesses.

The recommendations addressed to the government include: improving the formulation, timeliness and implementation of Serbian agricultural policy measures; improving the legal framework for lending to agribusinesses; and improving government support mechanisms and the institutional framework.

1. Improve the formulation, timeliness and implementation of Serbian agricultural policy measures:

- Establish an Agro Sector Financing Data Initiative.

- Put the agribusiness policy into the right context 
- Develop Agribusiness Development Strategy and set of policies

- Establish Agribusiness Council and intergovernmental Working Group on Agribusiness Development.

- Increase the capacity of the Directorate for Agrarian Payments and the Ministry of Agriculture.

2. Improve the legal framework for agribusiness:

- Develop and adopt a new Law on Agricultural Cooperatives.

- Develop and adopt the Commodity Exchange Law.

- Improve leasing regulation.

- Develop regulatory framework for the non-banking financial sector.

- Explore possibilities for improving banking regulation.

3. Improve government support mechanisms and institutional framework:

- Supporting innovations through government mechanisms.

- Introducing partial guarantees and risk sharing facilities.

- Establish the Agricultural Cadastre.

- Increase number of "public warehouses" and use of warehouse receipts.

Recommendations addressed to agribusinesses. Feedback from lending institutions indicates that borrower risk aversion, misperceptions, poor knowledge, and a weak credit culture are contributing to financing challenges and leading to negative sentiment. Furthermore, agribusinesses, and especially farmers, often lack the capacity to present their business to lenders. The challenges are compounded if they have limited or no formal credit history or cannot unwind business finances from their household finances (which is almost always true in case of farms), participate in the informal economy, etc. Most of these challenges can be overcome through the active efforts of agribusiness, business associations and clusters, as well:

- Strengthen the capacities of farmers and agribusinesses to access formal finance.

- Strengthen the capacity of business associations and clusters to improve access to finance for their members.

- Strengthen the capacity of business associations and clusters to advocate for reforms to improve access to finance for agribusinesses.

- Building capacity of value chains.

- Develop an agribusiness financing portal.

Recommendations addressed to the financial sector. Recommendations listed here serve to address many of the constraints identified by lenders that can be partially overcome if properly addressed by the financial sector (Galic et al., 2012). The recommendations are focused only on agribusiness-specific issues, excluding those that would generally improve access to finance for SMEs in Serbia: Develop agricultural insurance; Develop specialized credit skills and policies; and increase value chain finance (Miller, Jones, 2010). 


\section{Conclusion}

Despite the economic, social and political importance of the Serbian agricultural sector, its growth is still significantly slowed by a large number of constraints. However, major opportunities are present in Serbian agriculture. Emerging hypermarkets and increased incomes are leading to a higher domestic share of consumption of fresh and processed vegetables, which will directly influence the development of supply channels within the sector. Additionally, growing market linkages with nearby EU market chains have been causing local investors to move forward with investments in facilities. These investors, and their growers and suppliers located in Serbia, will need significant increases in financial support in the context of agricultural lending in order to meet their goals.

The conclusions of this study show that agricultural finance is provided at a much lower level in Serbia than would be anticipated judging by the importance of this sector to the country's economy and GDP. After detailed discussion of these issues with lenders and desk research, a number of specific interventions have been proposed here, especially as pertains to the roles of the MoA and MoFE in the facilitating environment for agricultural finance. Moreover, much can be done by agribusiness, the financial sector and in cooperation between those two without the government being involved.

The successful implementation of these policy recommendations can be expected to serve as substantial support for the development of agricultural lending in Serbia, particularly at the level of SMEs, start-ups, entrepreneurs, SMEs needing agricultural equipment, as well as of input financing for unregistered farmers.

These recommendations and findings have the support of the local stakeholders interviewed, including banks, leasing companies, most state funds, MFIs, business associations, etc. With a new government taking office, it is now a propitious moment to look into the possibilities of a strengthened research and lobbying effort, and to focus attention on the resolution of constraints to access to finance by agribusinesses.

\section{References}

1. Finansiski pregled lizinga, drugi kvartalni izveštaj, 2012, NBS, Beograd.

2. Galić, J., Petraković, D., Filipović, S. (2012): Finansijska infrastruktura i finansijsko tržište u Srbiji - stanje i neophodne promene, Ekonomski institut, Beograd.

3. Guarantee Fund of AP Vojvodina, internal data, 2012, Novi Sad.

4. Leasing Association of Serbia, internal data, 2012, Belgrade.

5. Miller, C., Jones, L. (2010): Agricultural Value Chain Finance, Tools and Lessons, Food and Agriculture Organization and Practical Action Publishing, Rugby, Warwickshire, UK.

6. NBS, internal data, Jun 2012, Belgrade.

7. Njegovan, Z. (2005): Risk analysis and Decission making process in agricultural enterprises of the CEEC, Industrija, vol. 33, no. 2-3, Ekonomski institut, Beograd, pp. 
$17-25$.

8. Njegovan, Z., Draganić, M. (2013): Cikličnost kretanja srpske privrede i neophodnost izbora novih industrijskih politika u agrarnom sektoru, zbornik - Globalna ekonomska kriza i poslovna ekonomija - izazovi teorije i prakse, EDUKONS, Sremska Kamenica, pp. 363-385.

9. Njegovan, Z., Filipović, M., Pejanović, R. (2009): Privredni sistem, politika i razvoj, Poljoprivredni fakultet, Novi Sad.

10.Njegovan, Z., Pejanović, R. (2009): Ruralna regionalizacija AP Vojvodine, Poljoprivredni fakultet, Novi Sad.

11. Pejanović, R., Njegovan, Z. (2009): Aktuelni problemi poljoprivrede i sela Republike Srbije, Industrija, vol. 37, no. 1, Ekonomski institut, Beograd, pp. 87-99.

12.Petraković, D., Filipović, S., Nedeljković, M. (2003): Main Characteristics and Tendencies of Banking System Development in South East European Transition Countries, ASECO, Economics Institute, Belgrade, pp.137.

13.Tomić, D., Njegovan, Z. (2013): Agriculture of the Western Balkan Countries in Globalisation and Liberalisation Processes, SANU, Beograd, pp. 1-16.

14.Zakon o Agenciji za kreditiranje i osiguranje izvoza, lex. spec., Službeni list Republike Srbije, br. 61/2005.

15.Zakon o poljoprivredi, Službeni list Republike Srbije, br. 41/2009.

16.Zakon o Razvojnom Fondu, Službeni list Republike Srbije, br. 88/10. 


\section{FINANSIRANJE POLJOPRIVREDE U SRBIJI: STANJE I PERSPEKTIVE}

\section{Ana Jolovič́, Zoran Njegovan ${ }^{6}$, Mirolsav Čavlin ${ }^{7}$}

\section{Rezime}

Srpska poljoprivreda već godinama ostvaruje relativno ograničene efekte. Jedan od značajnihfaktorajesteneprilagođenostfinansijskog sistema njegovim potrebama uprkos činjenice da postoji značajan broj različitih izvora finansijskih sredstava. To doprinosi da se dostupnost finansijskih sredstava za farmere i poljoprivredna MSP može oceniti kao najmanje adekvatna u poređenju sa drugim sektorima. Sprovodeći istraživanje o stanju i perspektivama finansiranja poljoprivrede u Srbiji, autori su postavili cilj ovoga rada da utvrde najveći broj relevantnih faktora na strani dosadašnjeg načina finansiranja, uoče tendencije postepenih promena u načinima finansiranja, kao i da ukažu na značaj dalje izgradnje ukupnog sistema agrarnog razvoja i infrastrukture, posebno na segmentu koji je od značaja za finansiranje.

Ključne reči: finansiranje, poljoprivreda, finansijske institucije, izvori finansiranja, banke, lizing organizacije, finansijski $i$ razvojni fondovi, mikrofinansijske organizacije, integratori.

5 Doc. dr Ana Jolović, University of Management and Economics ISM, Arkliu street 18, Vilnius, Lithuania, Telefon: +381 6375035 67, E-mail: anjol@faculty.ism.lt

6 Prof. dr Zoran Njegovan, redovni profesor, Univerzitet u Novom Sadu, Poljoprivredni Fakultet, Trg Dositeja Obradovića 8, 21000 Novi Sad, Telefon: +381 648465 062, E-mail: njegovan@polj.uns.ac.rs

7 Doc. dr Miroslav Čavlin, FIMEK, Cvećarska 2, 21000 Novi Sad, Srbija, Telefon: +381 21 400 484, E-mail: cmiros@gmail.com

EP 2014 (61) 1 (127-137) 
